\title{
The Transformation of Hymn Song in Local Church: a Study of Musical Style in Manado
}

\author{
Berehme Adyatmo Purba1, Lidya Kandowangko², Siguti Aprinnostein Sianipar ${ }^{3}$, Erwin \\ Sianturi ${ }^{4}$ \\ Faculty of Arts and Social Religion Studies \\ Faculty of Christian Education \\ Manado State Christian Institute \\ admopurba2@gmail.com¹,kandowangkolidya23@gmail.com²,gutistein89@gmail.com³, \\ kacamataerwin@gmail.com ${ }^{4}$
}

\begin{abstract}
Music in the worship of reformed Lutheran and Calvinist churches has a form of music that has been adapted to the ideological basis of the church. The form of hymn song is one of the church doctrines that must be carried out by church members. However, in its development, the reformed churches began to transform with the transform of hymns music arrangements into popular music compositions. So that the hymn song no longer matches the characteristics that are based on the rules of hymnology. Therefore, this research intends to analyze the transformation process of hymns arrangement which is usually sung in the worship of the reformed church, especially the local church, the Evangelical Christian Church in Minahasa (GMIM) located in GMIM KristusManado. This research was conducted based ona qualitative research method with descriptive analysis. In collecting data, researchers conducted a literature review and collect relevant information through online media, field observations by visiting churches that had composed hymns, and conducted in-depth interviews. The results of this study found the process of transformation of hymns song in varied Beat ostinato Element. There are elements of composition that changedthe form of melodic accompaniment, the develop popular rhythms, minimizing the progression of harmony, and have implications for changes in the structure of song form. The tendency of music in the church also prioritizes popular music aesthetics, at the same time considering the essence of thesong hymns. On the other hand, the arrangement of components in the hymn song to trigger the attraction and motivate the congregation in creative worship. Especially for young people in unstable and frequently move in varying churches. So that, hymn song, transforming to reach them and stimulate their enthusiasm in worship. This research is expected to be useful in the field of church music, especially music analysis studies, and rely on a social-cultural perspective to learn the current disruptive era.
\end{abstract}

Keywords: Local Church, Hymn Song, Music Analysis

\section{Introduction}

In the disruptive era, Harwibowo [1] mentioned that music also experiences this condition due to many things, one of which is the merging of genres into subgenres. Local reformed churches are confronting with progressive changes in the worship system. Especially, in church music developments which are dominated by hymn songs and interpreted with worship songs that are oriented towards biblical values. But apparently, hymn songs tend to be monotonous and static. We refer toMartasudjita, E \& Prier, Karl Edmund [2] inthis 
condition does not represent the needs of modern congregations which are influenced by the development of $20^{\text {th }}$-century music. Moreover, the church is challenged to be able to attract young congregation members who get bored quickly and they have euphoria with the newest gospel song or British style music in worship. Also, because of technology information provided many solutions for young people to find or download the newest songs from the internet, for example, media streaming on YouTube. In media streaming, many young people obtained categorization of music genre because playlist songs available and it always updated everyday based on Hughes [3] has identified the music industry in a disruptive era.

Local churches as if forced to be updated and adjust to the development of church music today. This is done to anticipate young people affected by the transformation of worship music (hymn) that loses spiritual meaning. Conceptually, hymn songs tend to be monotonous and less of progressively if only use one type of musical instrument.Prier [4] answersthe need for modern congregations especially young people,church music in the form of the hymn songs improves the composition of music adapted to the socio-cultural context of the community in which the church is located.

KomisiLiturgi dan MusikSinode GKI [5] adds hymn composers to compose hymn song compositions using musical elements with hymnody characters. In the process of creating hymn songs, Songwriter through deep reflection so that it has a theological meaning that is always associated with biblical elements. For Example,a song must correlate poetry with the tone, which aims so that the meaning of the poem can be described in a series of tones. Indirectly, hymn songs can stimulate the affective feelings of the congregation.

If a performer or accompanist in a musical service in the church does not know the theological theory of a song and the ability to arrange songs. This condition can have negative impacts because the music that is played does not fit into the existing worship context. So, the congregation feels disturbed by the music they don't normally sing.

Besides that, Panjaitan and Lumigkewas [6]Budiarto [7] emphasize the term contemporary music which is used as worship music in the local church. Contemporary music is better known by more modern music, both in terms of medium or instrument and in terms of musical elements. For example, the type of songs that usually sings in the church is praise and worship songs, gospel songs, and other popular music. The expert on church music often uses the term contemporary as a type of church music in nowadays. But, according toAmmer [8], if we review the history of contemporary terms based on the development of music in modern times that are classified,there is a difference in the understanding that is known by church music activists.

Therefore, it is necessary to conduct a fundamental review of the understanding of music used in the Church, so as not to be misunderstood by church musicians and even the congregation itself. Today, music knowledge within the church musicians is no longer essential needs. Because they are prepared only to have the skills to play as accompaniment congregational singing. Unlike the church musicians who lived in classical times who were required to study basic music in depth such as music theory, music history, or harmony. This problem is a benchmark to explore and analyze the musical framework contained in the local Church.

This research was conducted to analyze the transformation in musical elements of hymnal songs in the local church, examine the factors that influenced the transformation in hymn song, also the social impact that results. Therefore, this research can be used as a theoretical reference in the study of church music that focuses on the field of music analysis. Along with an empirical study of the social-cultural conditions of the congregation in the local church that underlies the transformation of hymnal songs in the worship process. 
Studies on hymnology especially in the study of church music analysis continue to develop and attract the interest of many academics from interdisciplinary. Hymn songs are not only positioned as songs orpoems, but are explored more deeply through historical aspects, cultural contexts, and social criticism.

The categorization of hymns is also present in the debates of theologians who study the passages of the Bible, which are considered to be a form of hymnal poetry like a study from Edsall and Strawridge [9]. They evaluated the study of the hymn songs from academics with a critical approach, especially the articles of Paul's letter in the New Testament. Due to the lack of empirical evidence that supports the scientific construction of poetry that can be indicated as a form of hymns.

Hymnal songs can also be criticized for presenting song lyrics that are not sensitive to gender equality. The study of hymns is expanded in the gender studies of Maria Samuelsson [10] which refers to the perspective of Luce Irigaray. Hymn poets in western cultural traditions and religious value frameworks are criticized for the superiority of the "Father" who tends to be patriarchal. The implication is subordinated in the depiction of the figure of the virgin Mary, who is always placed at the lower level. Poems on hymns that have theirsacredness are required to emphasize more gender equality.

In terms of idioms, in hymn poetry in some African societies, it is still influenced by colonial culture. Based on Bethke's [11] analysis of the transformation of South African musical idioms that emphasizes the reduction of diminished intervals in the colonial harmony system. Mention the existence of "localized westerns" which is a reference to the transformation of idioms from the hymnal tone in South Africa. This study also examines how local identity has relevance to the development of music, especially hymnal songs that are often sung by local communities.Although the Victorian style once dominated the style of music,the transformation in the formation of idioms and harmonization of tone continues. The hymnal tone transformation was used as a solution to create harmony by following the culture of the black community in South Africa.

The Colonial culture which tends to dominate hymn poetry demands transformation because it reinforces local identity. Such an interesting study from Jordaan [12] examined the process of singing hymnal songs as a form of identity claim. Based on his study, singing hymnal songs are a personal and communal expression, especially when it comes to contact with other cultures.And then, the hymn singing is no longer seen as a colonial legacy but is transformed with local characteristics that are freed from the influence of colonial culture.

The study of local traditions in hymn songs was also developed by Mkallya [13] regarding the effect and affection of religious songs in local traditions. The effect is they make many contributions, offerings very generously and enthusiastically. In terms of its affection, hymnal songs can help change the lives of congregations. The combination of the traditional attributes of Tanzanian music and aesthetics sticks together.

The issue of the locality also influences research fromQuan-Baffour [14], He examines the transformation in Ghanaian Christian songs triggered by a cultural foundation where music or songs from local people are still prohibited from been used as part of worship. Nevertheless, the love of the Ghanaian people for the cultural value of local music is so strong, so that made the integration of local cultural values through the rhythm and playing of musical instruments that produced acculturation by local and Christian worship cultures in contemporary Ghana community churches.

These studies emphasize that the study of hymnal song transformation shows important aspects to be studied. However, academics are more concerned about the dominance of colonial culture, especially the area that had been visited by missionary groups. Because the 
cultural values of missionaries influence hymn songs sung in the worship of local communities. External factors receive more attention, namely the colonial tradition which is often a reference in the transformation of hymn songs. The transformation has a variety of triggers that encourage changes in the arrangement and format of instruments, that are varied due to the needs of the community, especially internally the church congregation. Internal and external factors play an important role in the transformation of hymn songs, especially in local churches that require more deeply research.Therefore, this research was conducted by referring to the approach of analyzing church music regarding the transformation of hymn songs in the local church, especially in Manado.

\section{Research Method}

In this research, we use qualitative research methods with a descriptive analysis approach.The purposes of this research as part of a music analysis study. The focus of the research problem is the transformation of the hymn songs in the Manado local church, which is usually accompanied by using one instrument that has been transformed in a full-band format. Social analysis is also used to examine the factors driving the transformation of hymns to the full band format, along with its impact on the enthusiasm of the congregation in following the worship process since the hymn was changed.

The location of the research is one of the local churches in Manado which converted hymns into a full band format. The local church referred to in this research is "GMIM Kristus" Church as one of the Evangelical Church in Minahasa.Why we choose "GMIM Kristus" church? because due to the model of worship in the "KebaktianUmum 3", which is usually held in the afternoon having a model of worship that is different from other local churches. In this research, the informants who were the primary data sources were selected based on purposive sampling, this means we determined the informants involved in the process of the hymn arrangement, music players, worship leaders, coordinators who specialize in church art and music activities, as well as church ministers who contribute to the worship process. This research was conducted in 3 (three) months has started from September to November 2019. During those sections, we visited the local church regularly to collect data which are supported this research.

Research data obtained by the literature review,observation, and in-depth interviews. The literature review is done by collecting references or research journals related to hymnology, local church issues, and study of musical style. Supported by observations, namely participant observations because actively participating in the worship of the "GMIM Kristus" church, accompanied by a full band format.In the observation process, we also recorded all the processes of worship with a video recorder to deeply analyzing the music elements that have changed.The data collection was also carried out through in-depth interviewswith informants who played a role in the process of transforming hymns in the church. Therefore, we have interviewed their priests, musicians in the band, worship leader, singers, and some congregation who felt the impact of the worship process by hymn song's arrangement.

According to Stein [15], the steps of the analysis technique are first to record an audio song that has changed, then transcribe the audio into a notation (full score) using the Sibelius application. In the next step, we made the cutting bars to put all the musical elements to detect what part of the notation influenced the transformation of the hymn song. On the other side, we reduce all data transcripts from the informants, then we classified their arguments 
and narrations based on the scope of research. To examine the core of their perspectives relatesto our concern in this research.We emphasize our analysis in display data, both the notes bar shows the musical elements and the data transcripts show the arguments from all the informants. In the last session, we made a conclusion of data analysis based on data display included musical elements in score bars and results of data interviews which are proved the transformation of the hymn song in a local church.

\section{Result \& Discussions}

Music in worship is an integral part and usually be attached to the liturgy. However, Protestant church music since the 18th century has carried out liturgical renewal that has adapted to human needs at the time. It is considered that music has declined from Bach's era music standards.At that time the role of music shifted to creating devotion because it is only used as a means, it is no longer for common needs as a church. In the development of the Protestant church, music has a musical tradition with a choral style that is only one voice. The organ acts as a companion to the chorals but is sometimes also replaced by the chorals to lead the congregation. In the 17th century, the choral developed into four sounds lead by organs, of which the upper voice became part of the congregation than the other sounds of the organ.

For the hymn song's character part likesfour-part harmony, pairing texts to tunes harmonic rhythm and it does not have a chorus like most popular forms of music and the rhythm that is always equated in harmony. In the homophones texture section,the soprano always carries the main melody. Discussing hymn songs, in general, is interpreted as a musical work that has choral characteristics available with parallel harmony textures. Harmony can be used by a piano player or organ as an accompanying score for congregational singing. In the study of the hymn songs, there is a special science called Hymnology, which means the study of music, literature, and theology.

Hymn songs continue to be transformed due to music arrangements. The Music arrangement is creativity to rearrange a piece of music to obtain a new form. This statement emphasizes by Blatter [16] The arrangement is done by adding or subtracting musical elements so that the pieces of the musical structure become different and varied shapes.

\subsection{The Transformation of Hymn Song Analysis}

The hymn song used as the object of research is from a collection of songs in the book which is called "Kidung Puji Pujian Kristen (KPPK)"."GMIM Kristus" Church makes the book as a reference song for the liturgy and worship every week. Consisting of 425 titles of works in the form of hymns with Indonesian language poetry and also translated into Mandarin writing. KPPK's songs were created for the vocal in SATB formation written in block notation.

In the "KebaktianUmum 3"the songs that were delivered as whole worship no longer performed hymn songs, but already dominated by spiritual songs in the form of popular culture. Interestingly, some rules have to perform songs in the form of hymn songs to maintain the characteristics of the reformed church.

For example, a song called "Setia" from KPPK No. 381 is one of the songs sung in $3^{\text {rd }}$ public worship. "Setia" song is created in the Binary form or consists of two different themes and a terminated Coda. Prier [17], Miller [18] defined musical style are consists of two 
contrary parts.

Original songs based on the KPPK book created in the form of four sounds that have 3 stanzas and a part of Chorus. The chorus poem is repeated after the stanza is sung.

Stanza I :Di dalam dunia penuh dosa, s'lalu berubah langit pun goncang, dan iblis pun giat bekerja, banyak anak Tuhan tersesatlah. Apakah engkau juga bimbang hatimu kuatir tak berdaya? Bangkit bagi Tuhan di sorga, bagi Rajamu tetap setialah.

Chorus; Setia, setia, nyatakanlah tekadmu, setia, bekerja, setia bagi Rajamu, setia, setia, jangan pandang manusia, susah apa pun, tetap sandarlah, Tuhan tahu setiamu.

Stanza II :Jangan takut 'kan kuasa iblis, ataupun serangan manusia, taatlah p'rintah Panglimamu, kehendak-Nya harus kaupatuhlah. Bagai dibakar dalam api, tiada takut ancaman raja, m'reka sungguh gagah perkasa, sampai mati pun tetap setialah.

Stanza III :Haruslah kau s'lalu setia, hanya memperkenankan Tuhanmu, kesusahan bukan yang baka, 'kan diganti-Nya mahkota mulia. Ia 'kan kembali dan menyambut semua hamba-Nya yang setia, kelak Ia berkata, "Hai engkau, masuklah dan berjamu dengan-Ku."

\subsection{The Transformation of Composition Elements}

There is a significant musical element transformation that occurs in the hymn song called "Setia", that is on aspects Introduction Section, Harmonic, Rhytmic, and Coda Section. We describe in the description which are parts that change using the stages from music analysis system tools based on Christ and Richard [19] study music structures.

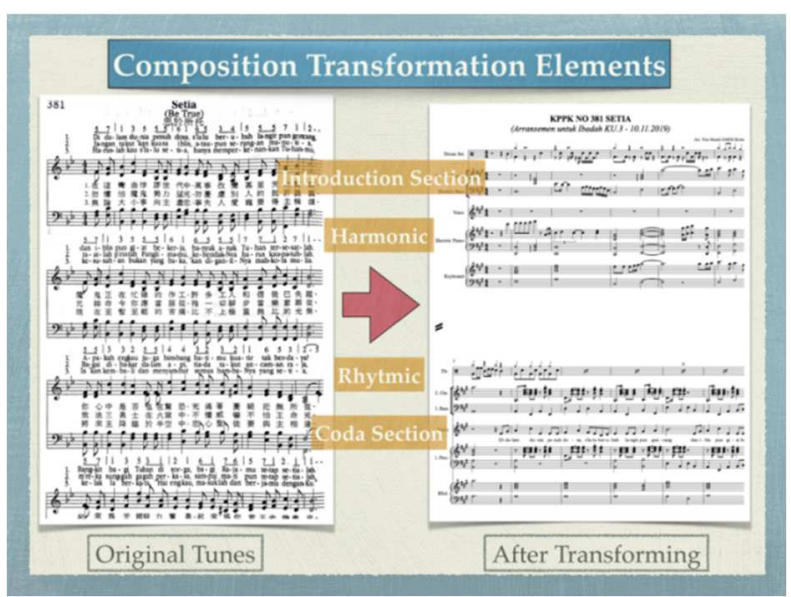

Fig.1. musical element transformation that occurs in the hymn song "Setia" 
There is a development of rhythmic motifs being diminished from pieces of motifs placed in the Introduction section. This piece of the motif is taken from the last phrase of the original song which is the 3 rd beatbut changed to have fermata as a sign of the coda.

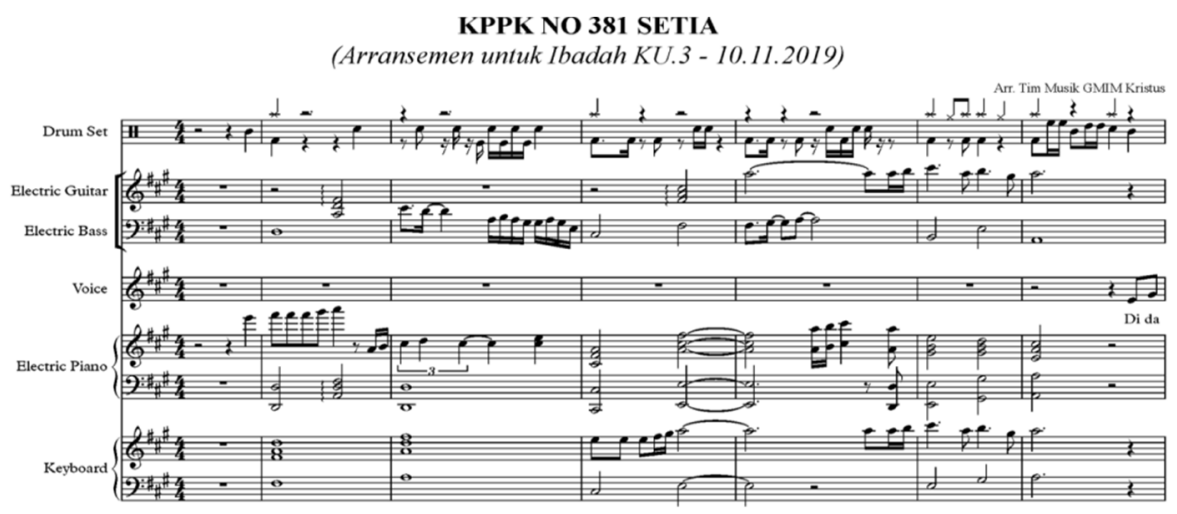

Fig.2. Example1 : Introduction Piece

The harmony changes occur when the basic tone changes that were originally made on the chord $\mathrm{Bb}$ major, but it was delivered to the chord A major or down 1 semitone. Changing musical scales affect the whole so that called transposition. With these changes, the game on the tonality of A Major also turns out to minimize the progression of harmony. For example in a phraseI (see: Fig.3.) has many progressions, while on songs that have been arranged (see: Fig.4.) in just one bar and moving in one chord.

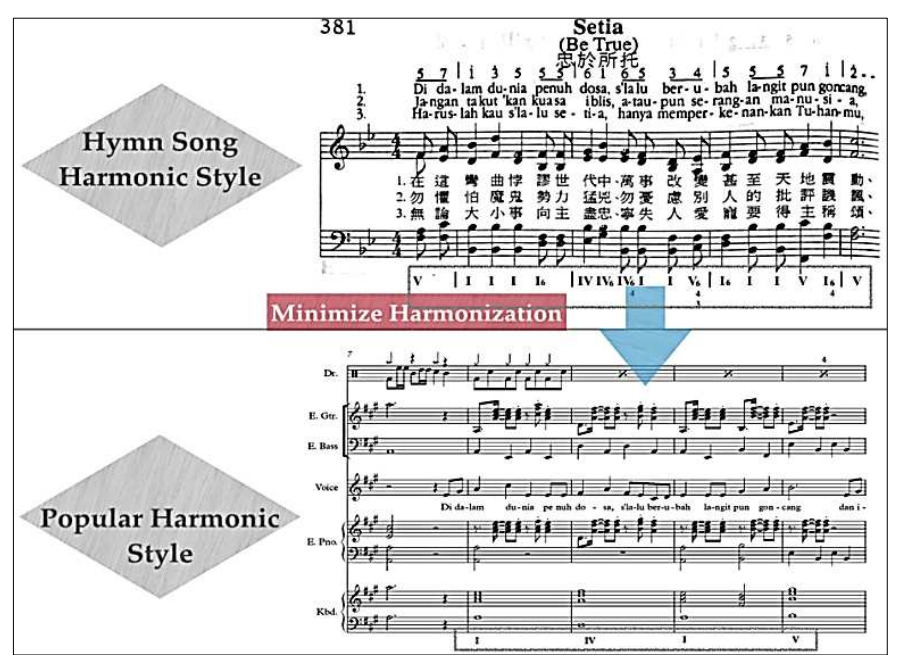

Fig.3. Example 3: APhrase I Transformation in Harmony

The next impact can be noted in the singer that the benchmark for determining the basic tone is the adjustment to the ability of the congregation. This proves one way to be able to adjust for the quality of the voice of the congregation which is generally young people. The 
youths considered the technique of singing popular songs still felt easier compared to the hymn song's character. The ability to sing high notes with individual vocal styles is still difficult to be adapted to the style of singing hymn songs that are essentially periodical. Because after all the technique of singing hymn songs is still maintained in the realm of the typology of musical hymn characteristics. Although there is a transformation in the accompanying music, some singers or congregations have not been influenced as a whole. Because if it is performed by the following the original keynotes printed on the scores, the congregation will find it difficult to reach the notes in the upper range.

The next phenomenon that occurs in music players or worship leaders who do not use music scores in guiding songs. They only rely on their feelings and memories during preparation, practice for Sunday service. Even in certain parts such as cadence or phrase division, there are improvised to add ornamental. The Culture of playing music like that is very common in many churches, especially in Charismatic churches. That is whythe culture of playing music has also gradually shifted the way music is presented. Because in the beginning in presenting hymn songs every player is always available score music contained in the hymnal book.

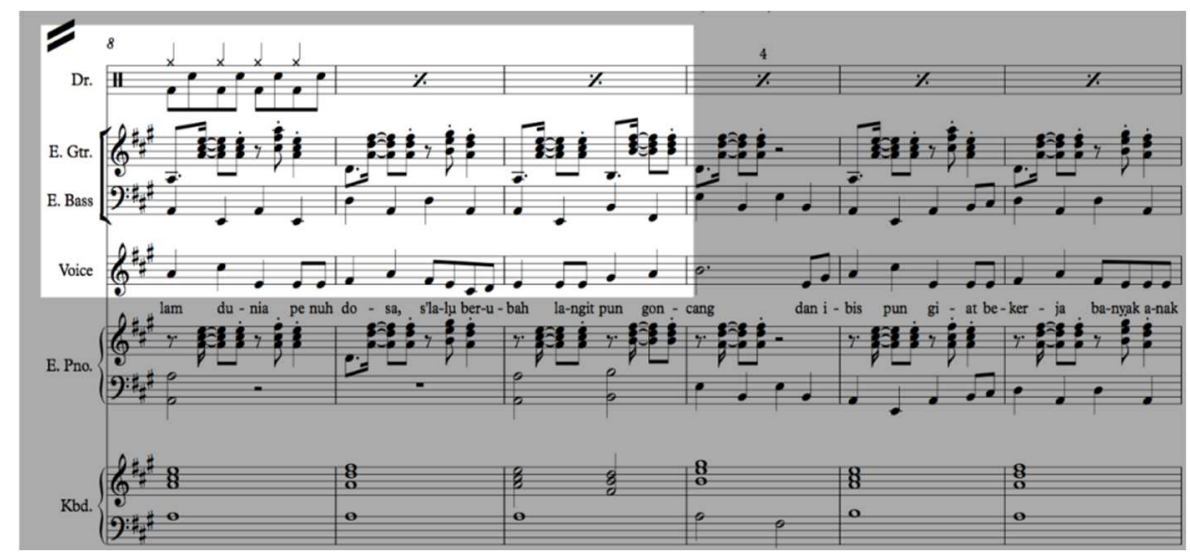

Fig.4. Example 4: Rhythmic Style Piece

The drum section shows the pattern constantly playing down-up, this musical element is called the ostinato pattern. The pattern of this song does not bring much variation, only in a few parts, namely in the introduction, coda, and at the end of the phrase only. Because the goal is to show more characteristics of new music styles that are different from the original song. That is why the down-up pattern is very dominant.

If you see the combination of drum patterns with electric bass instrument patterns have a correlation then there is harmony, more impressions appear on every count of quadruple actions. The rhythm pattern of an electric bass instrument is no different from a drum. Electric bass instruments still make chord changes even though they play ostinato patterns. Each chord change does not have many motives, because it only has one motive that dominates. Instruments that act as accompaniment move together to guide the path of the main melody.

Unlike the electric guitar which has a contrasting pattern from the instrument drum and electric bass. Each bar begins with the replacement of a root chord that falls into the down position, then followed by third and quint intervals in the up position repeated one octave higher. This rhythmic pattern becomes a typical accompanying model in this song. Each change of chord rhythm pattern is still the same as running ostinato, played with the addition 
of accentuation.

Repetition patterns like the one above often appear in pop songs that are easy to follow and sing at the same time. But in some final segments, there are electric bass games like a kind of improvisation, this shows the presentation of worship music that is flexible. Because the presentation in the form of a hymn has changed to like a presentation of pop music in general.The unavailability of music scores when accompanying congregations makes music players more freedom to play instruments without guidance. The drum also has a role to guide the course of other instruments and to equalize the beat count. However, if compared to Fig.2., there is a different rhythm pattern from the original song that is arranged in parallel. Simply, the rhythm pattern only follows the motives in the underlying melody.

The style of the hymn song has a calm tradition, it does not require repetitions that lead to the song expressive musically. Emphasis on hymn songs is more focused on aspects of poetry that have special meaning from a song's work.

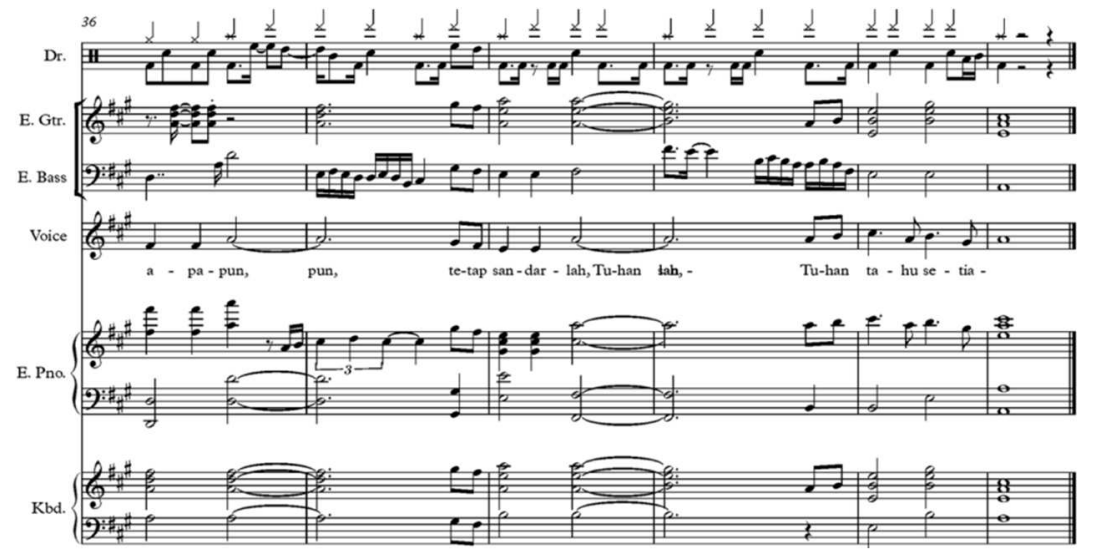

Fig.5. Example 5: Transformation in Coda

In the original song in the lyrics, there is a fermata. However, music processing in a full band does not use fermata, so that the affirmation of the sentence is aimed at all the verses in the last sentence. The impact on the atmosphere of the song that was composed from the beginning to the end of the song gives something that is wisdom, enthusiasm, and grateful. This is the atmosphere that we can find in the formation of the pop genre band.

\subsection{The Transformation of Hymn Song: An Answer for Young Generation Needs}

Explain the existence of musical transformation by comparing the hymn music performed by one instrument with many instruments or full band. There are differences in the atmosphere that appears before transforming there is a serene impression, but after transforming the atmosphere turns into a firm and energized. It turns out that increasing the number of musical instruments can create energy in the song. Therefore, transformed music can influence congregational worship and display more enthusiastic praise. The effects resulting from the transformation of the hymn song are not only in intra-musical elements such as rhythm, harmony, and instrumentation. But, it stimulates exercise in praise.

The process of transforming the hymn song to the local church aims to reach the congregation, especially young people. Guerra et al [20] examine youth culture and music have special reciprocal relations between them, especially in the crisis condition in the late 
era. Therefore, the local church must be adapted to the young narration about musical style in their own needs. To answer the needs of young people, they do have special tricks. Moreover, the local church is faced with the development of charismatic churches that offers worship with music that is more expressive and inspires young people's enthusiasm. Local Church in "GMIM Kristus" context could read the condition immediately by expanding the worship model that uses full band format music. Hymn songs are also transformed in fullband style with more instruments than conventional hymn styles. The transformation of worship affected the songs used more contemporary.Thomsen et al [21] examined the hymn song transformation to become contemporary style as "secular-hymn" in the post-modern era.Contemporary music comes from general terms related to time. Contemporary music is essentially creating a new musical element, a new music system, and new techniques in playing instruments and always developing.

\section{Conclusion}

Thus, the social-cultural context has a role in the transformation of the hymn songs in the local church. Conversely, the transformation of the hymn songshad an impact on the worship conditions of the congregation in "GMIM Kristus" Church. In terms of quantity, the number of people attending has increased and can be seen from the density of seats. The young people who become the main object behind the transformation of the hymn songs play an important role. The young people support in ministry by acting as worship leaders or those who play musical instruments in worship. Transforming hymn songs in creative Worship is one way to reach young people who frequently move to the church. Also, the liturgical concept remains the basis of reference even though it is combined with contemporary worship models.

This research also found a tendency for the element of music that was favored by the congregation in the $3^{\text {rd }}$ worship service, namely the varied Beat ostinato Element. This is due to the element of the Ostinato beat which can ignite enthusiasm, the congregation was pleased with the rhythmic style of secular pop music. In the intro section,it can be concluded that each song that begins with popular melodies with modern chord progressions can immediately raise a rapid response to the song and enthusiasm to sing the song.

\section{References}

[1] Harsawibawa, A. (2017) DisrupsiDalamMusik. Resital :JurnalSeniPertunjukan, 18 (3), 144-158

[2] Martasudjita, E \& Prier, Karl Edmund. 2009. MusikGereja Zaman Sekarang. Yogyakarta : Pusat MusikLiturgi

[3] Hughes, D., Evans, M., Morrow, G., \& Keith, S. (2016). New Music Industries: Disruption and Discovery. United States: Palgrave Macmillan.

[4] Prier, Karl Edmund. 2014. InkulturasiMusikLiturgi 1. Yogyakarta : Pusat MusikLiturgi

[5] KomisiLiturgi dan MusikSinode GKI. 2012.MusikdalamIbadah. Jakarta :GrafikaKreasIndo

[6] Panjaitan, F., Lumingkewas, M S. (2019). IbadahJemaat Kristen Kontemporer dan TinjauanKritis-Liturgis. Fidei: JurnalTeologiSistematika dan Praktika. 2(1), 162-185.

[7] Budiarto, Teguh C. 2001. Musik Modern dan Ideologi Pasar. Yogyakarta: Tarawang Press.

[8] Ammer, Christine. 2004. The Facts On File Dictionary of Music, Fourth Edition. New York: Facts On File, Inc. 
[9] Edsall, Benjamin \& R. Strawbridge. 2015. The Songs We Used to Sing? Hymn 'Traditions' and Reception in Pauline Letters. Journal for the Study of the New Testament 2015, Vol. 37(3) 290311

[10] Jansdotter Samuelsson, Maria. 2009. Redemption from Mother Nature to Our Father the Lord?* An Ecofeminist Analysis of Hymns in the Swedish Church Edition of Psalmeri 2000-talet. Journals Permissions.nav Vol. 18(1): 74-91

[11] John Bethke, Andrew. 2017. The Transforming Idioms of South African Hymn Tunes: Diminishing Residues of Colonial Harmonic Systems and the Reinterpretation of Hymn Tunes. Muziki, 14:1, 7-25

[12] Jordaan, Gerrit. 2013. Hymn singing in Sesotho/Setswana/Sepedi speaking churches: a process of claiming and reclaiming,Muziki: Journal of Music Research in Africa, 10:2, 39-55

[13] Mkallyah, Kassomo. 2016. Affects and Effects of Indigenous Tanzanian Traditional Music in Christian Worship in Dar es Salaam, Tanzania. University of Illinois Press on behalf of Society for Ethnomusicology, Vol. 60, No. 2 (Spring/Summer 2016), pp. 300-328

[14] Quan-Baffour, Kofi Poku. 2008. Transformation and acculturation in Ghanaian Christian songs. Muziki: Journal of Music Research in Africa, 5:2, 165-178

[15] Stein, Leon. 1979. Structure and Style. USA: Warner Bros, Publications

[16] Blatter, Alfred. 1980. Instrumentation / Orchestration. New York: (Drexel University) Schirmer Books, Division of Macmillan, Inc.

[17] Prier, Karl Edmund. 2017. IlmuBentukMusik. Yogyakarta : Pusat MusikLiturgi

[18] M. Miller, Hugh. 2017. ApresiasiMusik. Yogyakarta :Thafa Media Yogyakarta

[19] Christ, W. \& Richard, D. (tanpatahun). Introduction to Materials And Structure of Music. Prentice Hall, INC, Englewood Clifts, New Jerse.

[20] Guerra P., Feixa, C., Blackman, S., \&Ostegaard, J. (2020). Songs that Sing the Crisis: Music, Words, Youth Narratives in Late Modernity (Introduction to the Special Issue). Young, 28(1), 513.https://doi.org/10.1177\%2F1103308819879825

[21] Thomsen,Steven R., Quint Randle \& Matthew Lewis (2016) Pop Music andthe Search for the Numinous: Exploring the Emergence of the "Secular Hymn" in Post-ModernCulture, Journal of Media and Religion, 15:3, 146-155,DOI:10.1080/15348423.2016.1209392 